\title{
NOTES
}

\section{BLACK ROSY-FINCH: UTAH BREEDING RANGE UPDATE AND SURVEY RECOMMENDATIONS}

\author{
NEIL PAPROCKI, 1467 Alpowa St., Moscow, Idaho 83843; neilpaprocki@gmail.com \\ THERESA POPE, Utah Division of Wildlife Resources, 1115 N. Main St., Springville, \\ Utah 84663; tpope@utah.gov
}

The Black Rosy-Finch (Leucosticte atrata) is one of the least studied North American birds, owing to the inaccessibility and remoteness of its habitat (Johnson 2002). It breeds along cliffs and in talus in alpine areas from central Idaho east to western Montana and Wyoming, south to southern Utah, and west to Nevada and southeastern Oregon (Johnson 2002; Figure 1). The Wildlife Action Plan Joint Team of the Utah Division of Wildlife Resources (2015) has designated the Black Rosy-Finch a "species of greatest conservation need" in Utah because of inadequate understanding of its ecology and life history, particularly its breeding distribution. The species is threatened by climate change, as breeding habitat already constrained by mountain summits is predicted to rise in elevation (Romme and Turner 1991, Conrad 2015, Elsen and Tingley 2015). Here we summarize and update current knowledge of the Black Rosy-Finch's breeding distribution in Utah and provide recommendations for survey protocols throughout the state.

During the June-August breeding season, the Black Rosy-Finch has been documented in Utah in the La Sal, Raft River, Tushar, Uinta, and Wasatch mountains (summarized by Johnson 2002; Figure 1, Table 1). More recently, reports during the breeding season via eBird.org have come principally from the Uinta and Wasatch mountains in northern Utah, especially from an expanse $100 \mathrm{~km}$ long of alpine habitat within the Uinta Mountains (Conrad 2015; Figure 1). In the Wasatch Mountains of north-central Utah, E. C. Conrad (in 2013), Jay Langford (in 2015), and others (via eBird.org) have noted Black Rosy-Finches from the Broad's Fork Twin Peaks to the Mount Timpanogos region.

Observations during the breeding season outside of the Uinta and Wasatch mountains are few (Figure 1). Behle et al. (1963) first reported Black Rosy-Finches in the southern La Sal Mountains, collecting the female from a pair at the head of Dark Canyon. Additional sightings have been made in the northern La Sal Mountains, where two observations of a fledgling and adult near Mount Tomasaki, on 21 August 2008 and 25 July 2014, offer the only evidence of successful breeding in this mountain range (Utah Division of Wildlife Resources and U.S. Forest Service unpubl. data).

After several expeditions to the Deep Creek Mountains of west-central Utah, Behle (1955) failed to observe or collect the species there but noted that Walter P. Cottam observed several unidentified rosy-finches near Ibapah Peak, the highest point of these mountains, in June 1947. Richard Porter saw two possible rosy-finches at dusk on the north face of Bald Mountain on 4 June 1950. But French (1959) was unable to locate rosy-finches in the Deep Creek Mountains in June 1956. Miller (1955) concluded that the Black Rosy-Finch's occurrence in the Jarbidge Mountains of northeastern Nevada makes it probable that the sight record in June 1947 in the Deep Creek Mountains was likewise of L. atrata.

In the Raft River Mountains, Clayton M. White, Gary Lloyd, and Guy Musser observed family groups with young on 27 July 1961, and White collected a single breeding female at cliffs near the head of Clear Creek on 16 July 1962 (Behle et al. 1963). Subsequently, Richard E. Johnson (pers. comm.) observed adult and immature Black Rosy-Finches in this mountain range on 12 August 1978. In the Tushar Mountains, there have been no reports in the breeding season since Priscilla R. Summers, Josh 


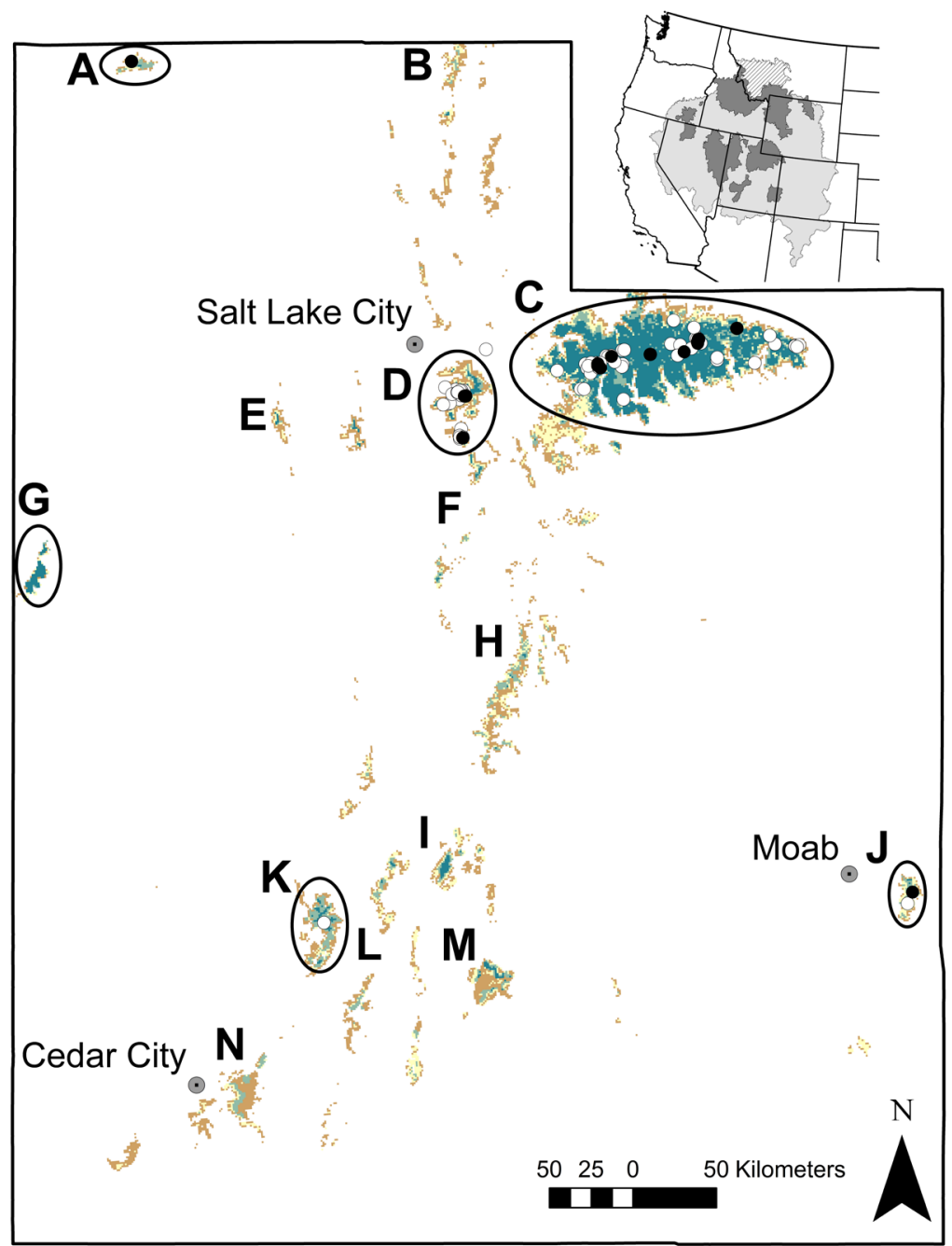

Figure 1. Occurrences and predicted distribution of the Black Rosy-Finch in Utah during the breeding season. The predicted distribution is a model based on a boosted regression tree modified from Conrad (2015). Areas with the highest probability of Black Rosy-Finch occurrence during the breeding season are represented in blue, followed in descending order of probability of occurrence by green, yellow, and tan. Circled mountain ranges indicate areas of known or suspected breeding. A, Raft River Mountains; C, Uinta Mountains; D, Wasatch Mountains; G, Deep Creek Mountains; J, La Sal Mountains; K, Tushar Mountains. Dots represent breeding-season records from Utah Natural Heritage Program (2018) and eBird.org. Black dots represent observations of breeding activity (e.g. nests, fledglings with adults); white represent observations without such evidence. Additional mountain ranges recommended for surveys for the Black Rosy-Finch during the breeding season are also shown: B, Bear River Mountains; E, Stansbury Mountains; F, Wasatch Mountains south of Mount Timpanogos; H, Wasatch Plateau; I, Fish Lake Hightop; L, Sevier Plateau; M, Aquarius Plateau; N, Markagunt Plateau. Inset: total range of the Black Rosy-Finch (hatching, summer only; dark gray, year round; light gray, winter only), modified from U.S. Geological Survey-Gap Analysis Project (2018). 


\section{NOTES}

Table 1 Utah Mountain Ranges in Which the Black Rosy-Finch Is Confirmed or Likely

\begin{tabular}{|c|c|c|c|c|}
\hline Mountain range & Location $^{a}$ & $\begin{array}{c}\text { Maximum } \\
\text { elevation }(\mathrm{m})\end{array}$ & $\begin{array}{l}\text { Evidence of } \\
\text { breeding }^{b}\end{array}$ & Source \\
\hline Raft River Mountains & A & 3028 & $\mathrm{RF}$ & $\begin{array}{c}\text { Behle et al. (1963); } \\
\text { Utah NHPc }\end{array}$ \\
\hline Bear River Mountains & B & 3042 & $\mathrm{~N}$ & \\
\hline Uinta Mountains & $\mathrm{C}$ & 4123 & $\mathrm{BR}$ & $\begin{array}{l}\text { French (1959); } \\
\text { Utah NHP }\end{array}$ \\
\hline Wasatch Mountains & D & 3581 & $\mathrm{RF}$ & $\begin{array}{l}\text { Behle and Selander } \\
\text { (1952); Utah NHP }\end{array}$ \\
\hline Stansbury Mountains & E & 3363 & $\mathrm{~N}$ & \\
\hline $\begin{array}{l}\text { South Wasatch } \\
\text { Mountains }\end{array}$ & $\mathrm{F}$ & 3636 & $\mathrm{~N}$ & \\
\hline Deep Creek Mountains & G & 3684 & $\mathrm{AD}$ ? & Behle (1955) \\
\hline Wasatch Plateau & $\mathrm{H}$ & 3440 & $\mathrm{~N}$ & \\
\hline Fish Lake Hightop & I & 3546 & $\mathrm{~N}$ & \\
\hline La Sal Mountains & $\mathrm{J}$ & 3879 & $\mathrm{RF}$ & $\begin{array}{l}\text { Utah Div. Wildlife } \\
\text { Resources and } \\
\text { U.S. Forest Service } \\
\text { unpubl. data }\end{array}$ \\
\hline Tushar Mountains & $\mathrm{K}$ & 3711 & $\mathrm{AD}$ & $\begin{array}{c}\text { Truan and Percival } \\
\text { (1999) }\end{array}$ \\
\hline Sevier Plateau & $\mathrm{L}$ & 3422 & $\mathrm{~N}$ & \\
\hline Aquarius Plateau & M & 3453 & $\mathrm{~N}$ & \\
\hline Markagunt Plateau & $\mathrm{N}$ & 3446 & $\mathrm{~N}$ & \\
\hline
\end{tabular}

${ }^{a}$ Figure 1.

${ }^{b} \mathrm{BR}$, nesting observed; $\mathrm{RF}$, recently fledged young; $\mathrm{AD}$, adults present during breeding season (June-August); $\mathrm{N}$, no evidence of breeding or no surveys.

cUtah Natural Heritage Program, Utah Division of Wildlife Resources, biotics database and files. Salt Lake City, examined December 2018.

Kreitzer, and Lew Wilkerson saw 8 individuals on 17 July 1999 (Truan and Percival 1999), and no evidence of breeding has been published.

In an effort to bolster breeding-season observations of Black Rosy-Finches outside of the Uinta and Wasatch Mountains, Paprocki made incidental surveys of potential breeding habitat in two remote mountain ranges in July 2018. On 7 July 2018, he observed Black Rosy-Finches at two separate locations in the southern La Sal Mountains, photographing a single adult foraging on a steep north spine of Mount Tukuhnikivatz $\left(38.4424^{\circ} \mathrm{N}, 109.2582^{\circ} \mathrm{W}\right.$; elevation $\left.3617 \mathrm{~m}\right)$ and observing another four individuals flying together above north-facing cliffs along the ridge between Mount Tukuhnikivatz and Mount Peale (38.4418 ${ }^{\circ} \mathrm{N}, 109.2446^{\circ} \mathrm{W}$; elevation $\left.3583 \mathrm{~m}\right)$. On 21 July 2018 , Paprocki and colleagues hiked to the top of Ibapah Peak (elevation $3684 \mathrm{~m}$ ) in the Deep Creek Mountains. No Black Rosy-Finches were encountered during this survey made above tree line from $39.8275^{\circ} \mathrm{N}, 113.9234^{\circ} \mathrm{W}$ to $39.8400^{\circ} \mathrm{N}, 113.9139^{\circ}$ W ( 1.5 km north of Ibapah Peak). Our survey was not comprehensive, however, and we encourage additional efforts in this mountain range.

Recent surveys for breeding Black Rosy-Finches within the state of Utah were combined with surveys of the American Pika (Ochotona princeps) and were mostly unsuccessful (Utah Division of Wildlife Resources unpubl. data). However, two significant resources can direct future targeted survey efforts within Utah and across the 


\section{NOTES}

Black Rosy-Finch's breeding range: the field protocol proposed by Montana Audubon (2017) and the predictive distribution maps for all of North America's rosy-finches developed by Conrad (2015). He found that a boosted regression tree performed the best of the models tested. Variables most important for this model were annual precipitation (representing 23\% of the variance the model explains), annual mean temperature (10\%), isothermality, and cliff (both 8\%; Conrad 2015). As cliffs are known to be associated with breeding Black Rosy-Finches (Johnson 2002), this model likely overpredicts potential breeding habitat, but it is the most accurate model currently available. As closely related rosy-finches have been found breeding in less typical habitat (i.e., north- and east-facing cirques below treeline, and in small isolated ranges or outlying portions of major ranges; Johnson 1975, Hendricks 1977), Conrad's maps could still be used as a basis for prioritizing broad areas for breeding-season surveys.

In light of the environmental influences of climate change on montane regions (Johnson 2002, Elsen and Tingley 2015), additional surveys will be critical to our still limited, but improving, understanding of the Black Rosy-Finch's breeding distribution (Brown et al. 2018). As recommended by Conrad (2015) and others, the mountain ranges given highest priority for surveys should be those where the probability of the Black Rosy-Finch's occurrence is highest. Areas with previous records need surveys as well if extirpations are to be documented. Efforts should also be directed at other ranges where the Black Rosy-Finch has been confirmed or suspected during the breeding season but have received less survey coverage, including the Deep Creek, La Sal, Raft River, and Tushar Mountains (Figure 1, Table 1). Finally, cliffs suitable for breeding (Johnson 1975, Montana Audubon 2017), but where the rosy-finch has not been documented, should be assessed, especially in the Bear River Mountains, Stansbury Mountains, Wasatch Mountains south of Mount Timpanogos, Wasatch Plateau, Fish Lake Hightop, Sevier Plateau, Aquarius Plateau, and Markagunt Plateau (Figure 1, Table 1). Other mountain ranges where the Black Rosy-Finch is possible (Conrad 2015) but likely lack cliffs suitable for breeding should be the lowest priority for surveys.

We thank the following individuals and organizations for contributions to this paper: Barb Smith (U.S. Forest Service) and Scott Gibson and Lisa Horzepa (Utah Division of Wildlife Resources) for permission to publish historical sightings from the La Sal Mountains; Keith Day (Utah Division of Wildlife Resources) for information on potential breeding habitat in southern Utah; Evan Buechley and Johnna Eilers for accompanying Paprocki to the Deep Creek Mountains; Ed Conrad for openly and generously sharing his thesis research on modeling the distribution of the rosy-finches; and Carl Brown for providing extremely helpful information on survey methods for the Black-Rosy Finch. We thank Paul Hendricks and Carl Brown for their reviews of the manuscript.

\section{LITERATURE CITED}

Behle, W. H. 1955. The birds of the Deep Creek Mountains of central western Utah. Univ. of Utah Biol. Ser. 11(4):1-34.

Behle, W. H., and Selander, R. K. 1952. New and additional records for Utah birds. Wilson Bull. 64:26-32.

Behle, W. H., Bushman, J. B., and White, C. M. 1963. Distributional data on uncommon birds in Utah and adjacent states. Wilson Bull. 75:450-456.

Brown, C. W., Patla, S., and Johnson, R. E. 2018. Extension of the breeding range of the Black Rosy-Finch in Wyoming. W. Birds 49:82-85; doi 10.21199/ WB49.1.7.

Conrad, E. C. 2015. Using species distribution models to quantify climate change impacts on the rosy-finch superspecies: An alpine obligate. Master's thesis, Univ. of Utah, Salt Lake City. 


\section{NOTES}

Elsen, P. R., and Tingley, M. W. 2015. Global mountain topography and the fate of montane species under climate change. Nat. Climate Change 5:772-776; doi $10.1038 /$ nclimate2656.

French, N. R. 1959. Distribution and migration of the Black Rosy Finch. Condor 61:18-29; doi 10.2307/1365342.

Hendricks, D. P. 1977. Brown-capped Rosy Finch nesting in New Mexico. Auk 94:384-385; doi 10.1093/auk/94.2.384.

Johnson, R. E. 1975. New breeding localities for Leucosticte in the contiguous western United States. Auk 92:586-589; doi 10.2307/4084615.

Johnson, R. E. 2002. Black Rosy-Finch (Leucosticte atrata), in The Birds of North America (A. Poole and F. Gill, eds.), no. 678. Birds N. Am., Inc., Philadelphia; doi $10.2173 /$ bna.678.

Miller, A. H. 1955. The breeding range of the Black Rosy Finch. Condor 57:306-307.

Montana Audubon. 2017. High alpine multi-species survey methodology. https:// www.montanabirdsurveys.com/uploads/4/9/1/6/49162743/high_alpine_ survey_methodology_2017_final.pdf.

Romme, W. H., and Turner, M. G. 1991. Implications of global climate change for biogeographic patterns in the greater Yellowstone ecosystem. Cons. Biol. 5:373-386; doi 10.1111/j.1523-1739.1991.tb00151.x.

Truan, V. A., and Percival, B. K. 1999. The nesting season: Mountain West region. N. Am. Birds 53:413-415.

U.S. Geological Survey —Gap Analysis Project. 2018. U.S. Geological Survey_Gap Analysis Project Species Range Maps CONUS_2001: U.S. Geological Survey data release, https://doi.org/10.5066/F7Q81B3R.

Utah Wildlife Action Plan Joint Team. 2015. Utah Wildlife Action Plan: A plan for managing native wildlife species and their habitats to help prevent listing under the Endangered Species Act. Utah Div. Wildlife Resources Publ. 15-14.

Accepted 8 January 2019 